\title{
Interpolasi Konsentrasi Polutan Timbal di DKI Jakarta Menggunakan Kriging Bayesian
}

\author{
Adina Astasia ${ }^{1, \text { a) }}$, Pardomuan Robinson Sihombing, 2 ,b \\ ${ }^{1}$ Badan Pusat Statistik Kabupaten OKU Timur, Jl. Adiwiyata Km 07 (SP. Lingot) Kota Baru Selatan \\ ${ }^{2}$ Badan Pusat Statistik, Jalan Dr. Sutomo No 6-8, Jakarta Pusat \\ Email: ${ }^{\text {a) }}$ adinaastasia@bps.go.id, ${ }^{\text {b) }}$ robinson@bps.go.id
}

\begin{abstract}
Jakarta is one of the most polluted cities in Southeast Asia. Pollution growth in Jakarta was quite high, along with the increase in the volume of motor vehicles. One of the pollutants that are dangerous as a result of incomplete combustion of vehicle engines is Lead $(\mathrm{Pb})$. Lead is dangerous for health, especially in children and pregnant women. Considering the importance of measuring air quality, including Lead $(\mathrm{Pb})$, DKI Jakarta Regional Environmental Management Agency (BPLHD) conducts air quality checks regularly. However, the high cost of monitoring air quality causes air quality to be measured only at a few points of observation location. Therefore, this paper aims to interpolate air quality at points not sampled using spatial interpolation or kriging techniques. Kriging is done by Bayesian method to consider parameter uncertainty in the variogram. The results showed that western Jakarta has the potential to have high lead pollutants compared to the central and eastern regions. In addition, a comparison between conventional and bayesian kriging methods, with the results of bayesian kriging, has a smaller variance than conventional kriging.
\end{abstract}

Keywords: air quality, interpolation, variogram, spatial, variance.

\begin{abstract}
Abstrak
Jakarta merupakan salah satu kota paling tercemar di Asia Tenggara. Pertumbuhan polusi di Jakarta pun cukup tinggi seiring dengan pertumbuhan volume kendaraan bermotor. Salah satu zat pencemar yang berbahaya sebagai hasil pembakaran tidak sempurna mesin kendaraan adalah Timbal (Pb). Timbal berbahaya bagi kesehatan terutama pada anak-anak dan ibu hamil. Mengingat pentingnya pengukuran kualitas udara, termasuk Timbal $(\mathrm{Pb})$ maka BPLHD (Badan Pengelola Lingkungan Hidup Daerah) Provinsi DKI Jakarta melakukan pemeriksaan kualitas udara secara berkala agar dapat menjamin kualitas udara di Jakarta. Namun, mahalnya biaya pemantauan kualitas udara ini menyebabkan kualitas udara hanya diukur pada beberapa titik lokasi pengamatan. Oleh karena itu, makalah ini bertujuan untuk melakukan interpolasi kualitas udara pada titik-titik yang tidak tersampel menggunakan teknik interpolasi spasial atau kriging. Kriging dilakukan dengan metode Bayesian untuk mempertimbangkan ketidakpastian parameter dalam variogram. Hasil penelitian menunjukkan Jakarta bagian barat berpotensi memiliki polutan timbal yang tinggi dibandingkan wilayah pusat dan timur. Selain itu, dilakukan perbandingan antara metode kriging konvensional dan bayesian, dengan hasil kriging bayesian memiliki varians yang lebih kecil dibandingkan kriging konvensional.
\end{abstract}

Kata-kata kunci: kualitas udara, interpolasi, variogram, spasial, varians. 


\section{PENDAHULUAN}

Jakarta dan Hanoi adalah dua kota paling terpolusi di Asia Tenggara (Greenpeace, 2019). Di Asia, Beijing merupakan salah satu kota yang terkenal tercemar. Namun, kualitas udara Beijing semakin baik, sementara kualitas udara di Jakarta semakin memburuk. Berdasarkan laporan dari AirVisual IQAir, konsentrasi rata-rata tahunan PM2,5 (Particulate Matter 2.5) pada tahun 2018 di Jakarta sangat tinggi, Jakarta Selatan mencapai $42,2 \mu \mathrm{g} / \mathrm{m}^{3}$ (42,2 mikrogram per meter kubik) sementara Jakarta Pusat mencapai 37,5 $\mu \mathrm{g} / \mathrm{m} 3$. Dapat dikatakan bahwa konsentrasi PM2,5 di Kota Jakarta mencapai empat kali lipat di atas batas aman rata-rata tahunan menurut standar Badan Kesehatan Dunia (WHO), yaitu $10 \mu \mathrm{g} / \mathrm{m} 3$, bahkan melebihi batas aman rata-rata tahunan menurut standar nasional pada PP No. 41 Tahun 1999 tentang Pengendalian Pencemaran Udara, yaitu $15 \mu \mathrm{g} / \mathrm{m} 3$.

Selain PM 2,5, zat pencemar lain sebagai dampak meningkatnya jumlah kendaraan bermotor adalah Timbal. Timbal $(\mathrm{Pb})$ dihasilkan dari pembakaran yang kurang sempurna pada mesin kendaraan. Logam $\mathrm{Pb}$ di alam tidak dapat didegradasi atau dihancurkan dan disebut juga sebagai non essential trace element yang paling tinggi kadarnya, sehingga zat ini sangat berbahaya jika terakumulasi pada tubuh dalam jumlah yang banyak (Gusnita, 2012). Ada dua bentuk Logam Pb yang mencemari udara, yaitu bentuk gas dan partikel-partikel. Timbal sangat berbahaya terutama pada anak-anak dan ibu hamil. Salah satu dampaknya yaitu kemunduran IQ dan kerusakan otak yang ditimbulkan dari emisi timbal ini. Selain itu timbal berbahaya karena dapat mengakibatkan perubahan bentuk dan ukuran sel darah merah yang mengakibatkan tekanan darah tinggi.

BPLHD (Badan Pengelola Lingkungan Hidup Daerah) Provinsi DKI Jakarta melakukan pemeriksaan kualitas udara secara berkala dapat memantau kualitas lingkungan. Namun, mahalnya biaya pemantauan kualitas udara ini menyebabkan kualitas udara hanya diukur pada beberapa titik lokasi pengamatan, yaitu Kalideres, Gambir, Ancol, KBN Cakung, JIEP, Kramat Pela, Ciracas, Tebet, dan Kuningan. Oleh karena itu, peneliti tertarik untuk melakukan interpolasi kualitas udara pada titiktitik yang tidak tersampel menggunakan teknik interpolasi spasial atau kriging.

Penelitian terdahulu mengenai kriging kualitas udara pernah dilakukan oleh Setiyowati (2015). Kualitas udara yang diukur yaitu Sulfur Dioksida $\left(\mathrm{SO}_{2}\right)$ dan Nitrogen Dioksida $\left(\mathrm{NO}_{2}\right)$ dengan lokasi pengamatan di DKI Jakarta menggunakan metode cokiriging. Namun metode cokriging yang merupakan metode kriging konvensional tidak mempertimbangkan ketidakpastian parameter dalam variogram. Sehingga pada makalah ini digunakan Bayesian Kriging yang menggunakan informasi prior mengenai parameter kemudian di-update dengan data yang ada untuk menghasilkan interpolasi yang lebih berkualitas.

\section{METODE PENELITIAN}

\section{Sumber Data dan Variabel Penelitian}

Data pencemar Timbal $(\mathrm{Pb})$ pada sembilan titik lokasi pengamatan, yaitu Gambir, Kalideres, Cakung, Ancol, JIEP, Ciracas, Kramat Pela, Tebet, dan Kuningan diperoleh dari BPLHD DKI Jakarta. Tabel 1 berikut adalah lokasi dan koordinat dari lokasi pengamatan kualitas udara.

Tabel 1. Lokasi dan koordinat bujur lintang lokasi pengamatan kualitas udara

\begin{tabular}{clcc}
\hline Titik & \multicolumn{1}{c}{ Lokasi } & Bujur (Longitude) & Lintang (Latitude) \\
\hline 1 & Pegadungan, Kalideres & $-6,140038$ & 106,702566 \\
2 & Gambir & $-6,168936$ & 106,832319 \\
3 & Ancol 1 (BPLHD) & $-6,123541$ & 106,831843 \\
4 & KBN Cakung, Cilincing & $-6,148427$ & 106,934417 \\
5 & PT. JIEP, Rawa Terate & $-6,185969$ & 106,913169 \\
6 & Kebayoran Baru & $-6,248503$ & 106,797112 \\
7 & Ciracas & $-6,329040$ & 106,879105 \\
8 & Tebet Barat & $-6,231064$ & 106,849358 \\
9 & Kuningan (BPLHD) & $-6,223052$ & 106,834267 \\
\hline
\end{tabular}

Sumber: BPLHD DKI Jakarta 


\section{Variogram}

Variogram sangat berguna untuk analisis data geostatistik (PJ.Diggle, 2002). Variogram yang digunakan didapat berdasarkan informasi keragaman data spasial dengan pengukuran jarak yang berfungsi untuk menentukan jarak dimana nilai data antar pengamatan tidak lagi saling mempengaruhi. Variogram ini dilambangkan dengan simbol $2 \gamma(\cdot)$, sedangkan semivariogram merupakan setengah dari variogram dengan lambang $\gamma($ ) . Formulasi semi-variogram adalah sebagai berikut:

$$
\hat{\gamma}(t)=\frac{1}{2 n(t)} \sum_{h_{i}, h_{j} \in n_{n}(t)}\left[Z\left(h_{i}\right)-Z\left(h_{j}\right)\right]^{2}
$$

dengan $\gamma(t)$ adalah variansi antara $Z\left(h_{i}\right)$ yang diketahui dan $Z\left(h_{\tilde{i}}\right)$ yang tidak diketahui saat jarak ${ }^{t}$ meningkat, dan ${ }^{n}$ adalah total observasi.

Variogram terdiri dari variogram empiris dan variogram teoritis. Variogram empiris diperoleh dari hasil pengukuran korelasi spasial antar data yang dipisahkan oleh jarak (h) tertentu. Dapat dikatakan bahwa variogram empiris diperoleh berdasarkan data. Namun, untuk tujuan analisis, variogram empiris harus diganti dengan variogram teoritis. Variogram teoritis merupakan variogram yang mempunyai bentuk kurva mendekati variogram empiris.

Semivariogram memiliki 3 parameter, yaitu sill $\left(\sigma^{2}\right)$, range $(\phi)$, dan nugget $(\beta)$. Sill $\left(\sigma^{2}\right)$ adalah nilai semivariogram saat besarnya jarak konstan atau saat semivariogram telah mencapai range $(\phi)$, artinya setelah semivariogram mencapai sill tidak ada lagi korelasi antar pengamatan. Nilai varians data dan sill $\left(\sigma^{2}\right)$ bisa sama besarnya. Range $(\phi)$ merupakan lag saat semivariogram mencapai nilai sill yang diasumsikan bahwa autokorelasi di luar range sama dengan 0 . Sedangkan nugget $(\beta)$ merupakan nilai semivariogram dengan lag mendekati nol. Nugget menunjukkan varians pada jarak yang sangat kecil, juga termasuk kesalahan pengukuran.

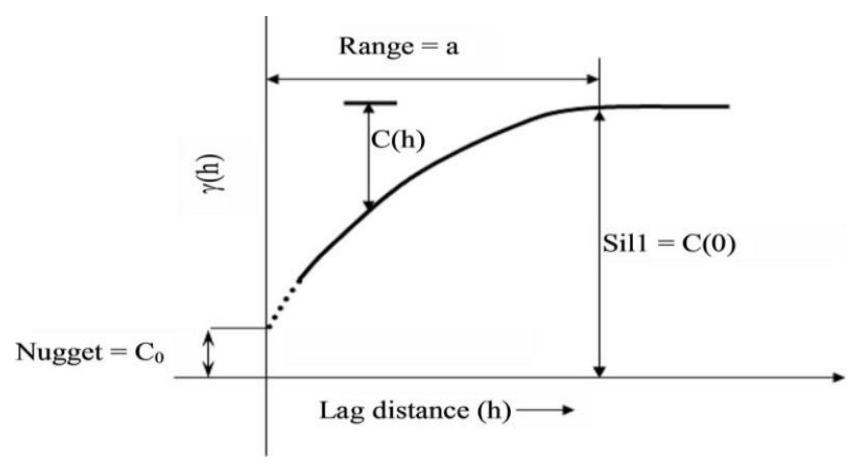

GAMBAR 1. Komponen Semivariogram

\section{Kriging}

Dalam analisis spasial teknik interpolasi yang digunakan adalah Kriging. Teknik ini menggunakan autokorelasi spasial antar lokasi tersampel untuk meprediksi nilai variabel di lokasi yang tidak tersampel. Kata "kriging" berasal dari D.G. Krige yang mengembangkan suatu metode pendugaan kadar mineral pada lokasi-lokasi tidak tersampel menggunakan nilai kadar mineral pada lokasi-lokasi tersampel (Setiyowati, 2015). Berdasarkan variabel teregionalnya, kriging dikembangkan menjadi tiga jenis, yaitu ordinary kriging, universal kriging, dan blok kriging. Pada ordinary kriging, penduga dibentuk untuk variabel teregional yang berfluktuasi pada level yang cenderung tetap. Pada universal kriging, penduga dibentuk untuk kasus dengan adanya tren dalam variabel teregional. Sedangkan penduga pada blok kriging dibentuk untuk mengestimasi rata-rata spasial variabel teregional. Rata-rata spasial merupakan rata-rata nilai variabel dengan bobot lokasi variabel tersebut. 


\section{Bayesian Kriging}

Selain metode-metode kriging konvensional, pengetahuan prior tentang parameter-parameter dalam variogram dapat diintegrasikan dalam ranah Bayesian. Pengetahuan prior mengenai variogram tersebut digunakan untuk mengupdate data untuk meningkatkan kualitas kriging. Bayesian kriging dapat dikatakan sebagai perluasan universal kriging, dimana pada universal kriging mempertimbangakan data tren pada $\mathrm{x}$ dan $\mathrm{y}$, tetapi tren pada bayesian kriging adalah distribusi prior dari parameterparameter dalam variogram seperti koefisien, variansi data, range, nugget, dan sebagainya. (Cui et al dalam Al-Mudhafar, 2019).

Parameter model dalam Bayesian Kriging diestimasi dari distribusi posterior berdasarkan Teori Bayes's:

$$
p(\theta \mid Z) \propto f(Z \mid \theta) p(\theta)
$$

dengan $p(\theta \mid Z)$ adalah fungsi likelihood dan $p(\theta)$ adalah distribusi prior sementara $Z$ adalah parameter yang diobservasi. $\theta$ adalah vektor dari parameter model (variogram). $p(Z \mid \theta)$ dan $p(\theta)$ merupakan distribusi posterior dan prior. $f(z \mid \theta)$ adalah fungsi maksimum likelihood yang bergantung pada fungsi-fungsi successive (fungsi pendukung) lain seperti pada persamaan (2). Asumsi dalam model bayesian kriging adalah parameter-parameter variogram yang dihasilkan berdistribusi normal dengan koefisien $\beta$ (nugget) dengan sill (varians) $\sigma^{2}$ seperti pada persamaan berikut:

$$
(Z \mid \theta) \sim N\left(\beta, \sigma^{2} C(\phi)+\tau^{2} I\right)
$$

dengan $\mathrm{Z}$ merupakan vektor dari parameter target, $\theta$ adalah vektor dari parameter-parameter variogram, $C(\phi)$ merupakan matriks korelasi dengan range $\phi$ dan $\tau^{2}$ merupakan kesalahan pengukuran. (Diggle and Riberio Jr, 2015) .

Distribusi prior dalam bayesian kriging merupakan koefisien dari variogram: sill $\left(\sigma^{2}\right)$, range $(\Phi)$, atau nugget $(\beta)$, sehingga distribusi prior $f(\theta)$ memiliki persamaan:

$$
f(\theta)=f(\beta) f\left(\sigma^{2}\right) f(\phi) f\left(\tau^{2}\right)
$$

distribusi posterior dari koefisien $\beta$ untuk parameter $Z$ dapat ditulis

$$
f(\beta \mid Z=z)=\iiint f\left(\beta, \sigma^{2}, \phi, \tau^{2} \mid z\right) d \sigma^{2} d \phi d \tau^{2}
$$

Persamaan tersebut dapat disederhanakan menjadi

$$
f(\beta \mid Z=z) \propto f(\beta) \iiint f(z \mid \theta) f\left(\sigma^{2}\right) f(\phi) f\left(\tau^{2}\right) d \sigma^{2} d \phi d \tau^{2}
$$

Model dasar final yang mengandung seluruh efek kemungkinan spasial (sill dan range) dan kemungkinan non-spasial (nugget) diilustrakasikan dalam persamaan

$$
z(h)=\mu(h)+\omega(h)+e(h)
$$

dengan $\mu(h)$ adalah nilai rata-rata dari ${ }^{X}$ pada jarak lag $h, \omega(h)$ adalah efek sill dan range, sedangkan $E(h)$ adalah efek nugget.

\section{HASIL DAN PEMBAHASAN}

Kandungan timbal pada sembilan titik lokasi pengamatan berbeda-beda dengan ringkasan data ditunjukkan pada Tabel 2.

TABEL 2. Ringkasan Data Penelitian, Konsentrasi Timbal $\left(\mu \mathrm{g} / \mathrm{Nm}^{\mathrm{a}}\right)$

\begin{tabular}{rrrrrr}
\hline Minimal & Kuantil I & Median & Rata-Rata & Kuantil III & Maksimal \\
\hline $\mathbf{0 , 1 0 9 4}$ & 0,1183 & 0,1331 & 0,2036 & 0,1720 & 0,6267 \\
\hline
\end{tabular}

Sumber: Hasil Olah Data 
Pada Gambar 2 terlihat bahwa kandungan timbal tertinggi berada pada lokasi pengamatan pertama, yaitu Kalideres, pada lokasi keenam, Kebayoran Baru,berada di posisi kedua. Seperti diketahui bahwa kedua lokasi ini berdekatan dengan Tangerang yang merupakan pusat industri sehingga dimungkinkan kadar Timbal pada lokasi-lokasi tersebut tinggi. Rata-rata kandungan timbal pada sembilan lokasi pengamatan adalah $0,2036 \mu \mathrm{g} / \mathrm{Nm}^{\mathrm{a}}$ dengan nilai minimum $0,1094 \mu \mathrm{g} / \mathrm{Nm}^{\mathrm{a}}$ (lokasi kedua, Gambir) dan nilai maksimum $0,6267 \mu \mathrm{g} / \mathrm{Nm}^{\mathrm{a}}$ (lokasi pertama, Kalideres).

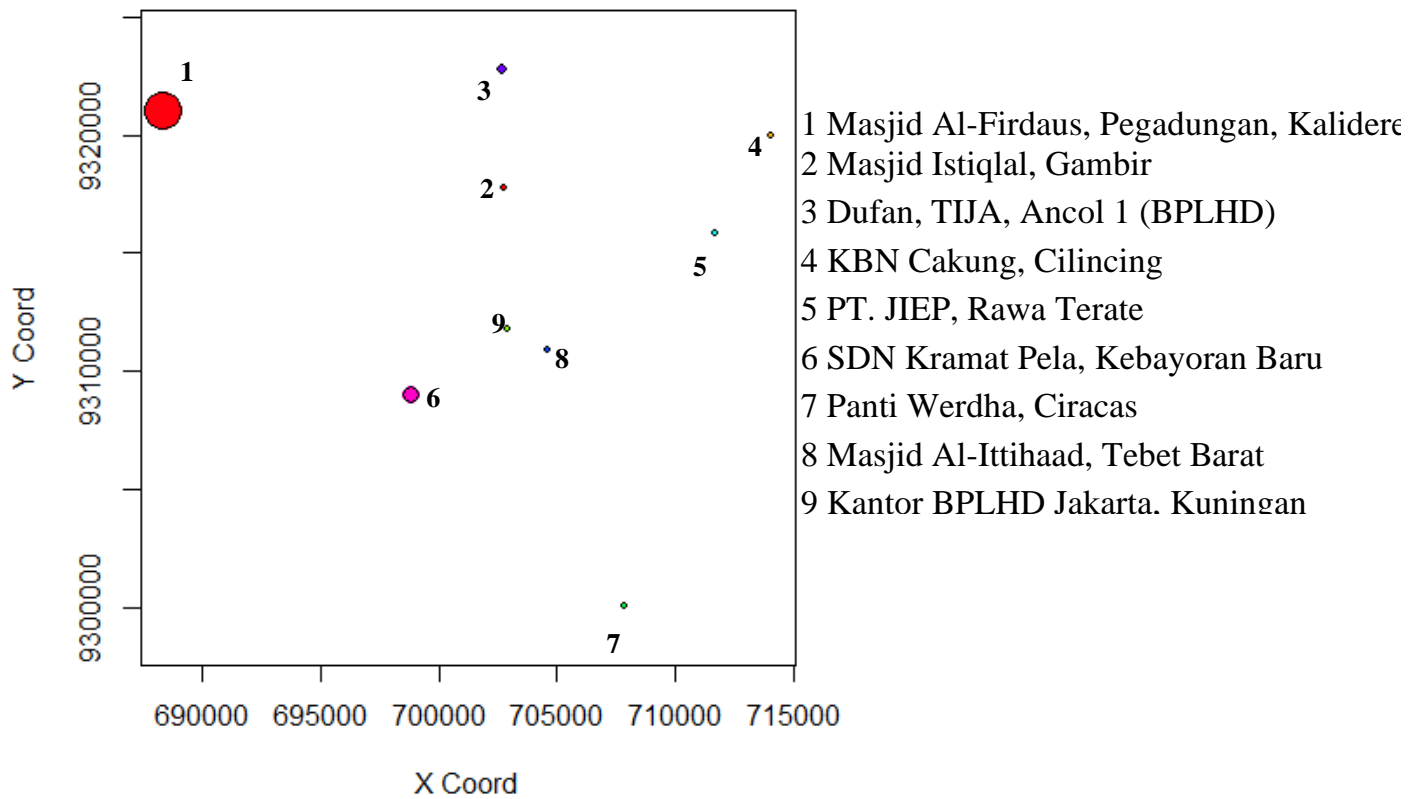

GAMBAR 2. Konsentrasi Timbal ( $\mu \mathrm{g} / \mathrm{Nm}^{\mathrm{a}}$ ) pada Sembilan Lokasi Pengamatan

\section{Uji Keberadaan Autokorelasi Spasial}

Sebelum dilakukan analisis lebih lanjut, dilakukan uji keberadaan Autokorelasi Spasial untuk mengidentifikasi adanya efek spasial, yaitu autokorelasi/dependensi spasial. Hasil uji keberadaan autokorelasi spasial diuraikan pada tabel berikut:

TABEL 3. Uji Keberadaan Autokorelasi Spasial Moran Index Test for Autocorrelation

\begin{tabular}{ccc}
\hline \multicolumn{3}{c}{ Moran Index Test for Autocorrelation } \\
\hline Moran I statistic standard deviate $=1,86, p$-value $=0,03144$ \\
\hline Moran I Statistic & Expectation & Variance \\
\hline 0,08235348 & $-0,12500000$ & 0,01242790 \\
\hline Sumber: Hasil Olah Data & &
\end{tabular}

Berdasarkan hasil uji Moran Indeks yang terlihat pada Tabel 3 diperoleh nilai $p$-value sebesar $0,03144<\alpha(=0,05)$ yang mengindikasikan bahwa terdapat dependensi spasial sehingga interpolasi dapat dilanjutkan.

\section{Variogram Empiris}

Variogram dihitung menggunakan dua estimator, yaitu modulus dan classical estimator yang disajikan sebagai berikut. 
classical estimator

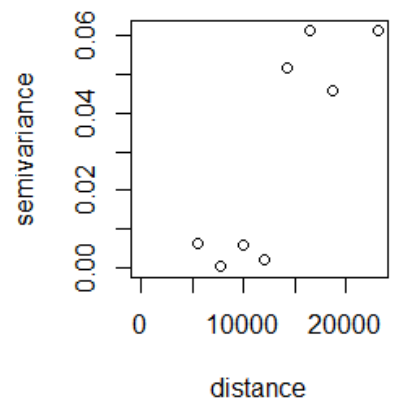

modulus estimator

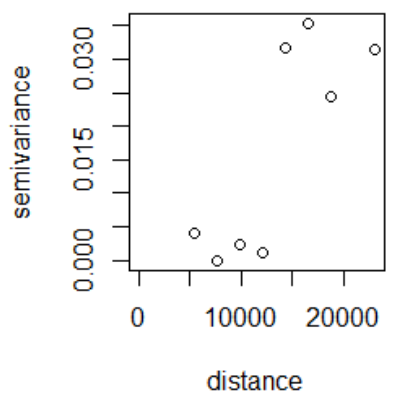

GAMBAR 3. Variogram empiris

\section{Estimasi Parameter}

Variogram empiris dan teoritis selanjutnya dibandingkan untuk mendapatkan estimasi parameter. Dalam prakteknya, nilai parameter sesungguhnya tidak diketahui sehingga dilakukan estimasi dengan beberapa cara seperti:

1. Eye estimate, memplotkan beberapa model variogram yang berbeda dengan variogram empiris

2. Least Squares Fit of Empirical Variograms, menggunakan Odinary Least Square (OLS) atau Weighted Least Square (WLS)

3. Likelihood Based Methods

4. Bayesian Methods

dalam makalah ini digunakan metode yang keempat yaitu Bayesian. Pada metode Bayesian, parameter variogram posterior (sill $\left(\sigma^{2}\right)$, range $(\phi)$, dan nugget $\left(\tau^{2}\right)$ ) berasal dari parameter variogram prior yang telah di-update dengan informasi data penelitian, yaitu data polutan timbal pada lokasi tersampel di Jakarta. Dengan menggunakan kedua informasi tersebut (informasi prior dan data) diperoleh parameter variogram posterior yang lebih baik dibandingkan parameter priornya.

Konvensional Kriging menghasilkan parameter variogram yang bersifat deterministik. Berbeda dengan Konvensional Kriging, parameter variogram pada Bayesian Kriging bersifat probabilistik, dimana diasumsikan parameter-parameter ini berdistribusi normal. Histogram dari parameter variogram posterior pada Bayesian Kriging data polutan timbal di Jakarta disajikan pada Gambar 4.
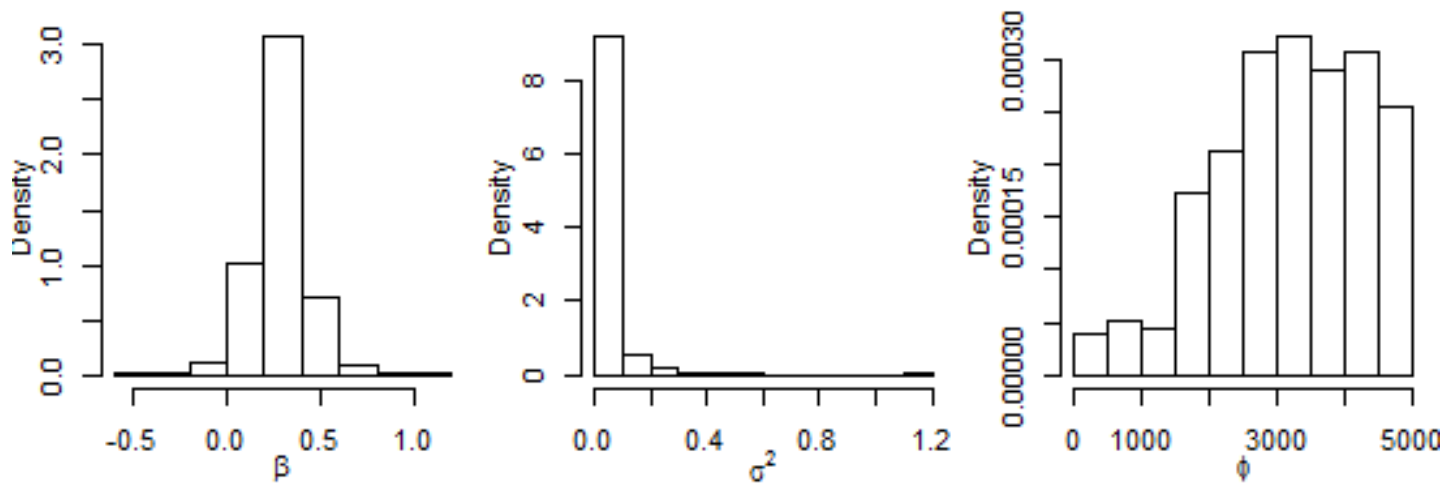

GAMBAR 4. Histogram dari parameter variogram posterior $\left(\beta=\right.$ nugget, $\sigma^{2}=\operatorname{sill}$, $\phi=$ range $)$

Variogram empiris kemudian dibandingkan dengan estimated Bayesian variograms menggunakan ringkasan dari distribusi parameter variogram posterior (rata-rata, median, modus) pada Gambar 5. 


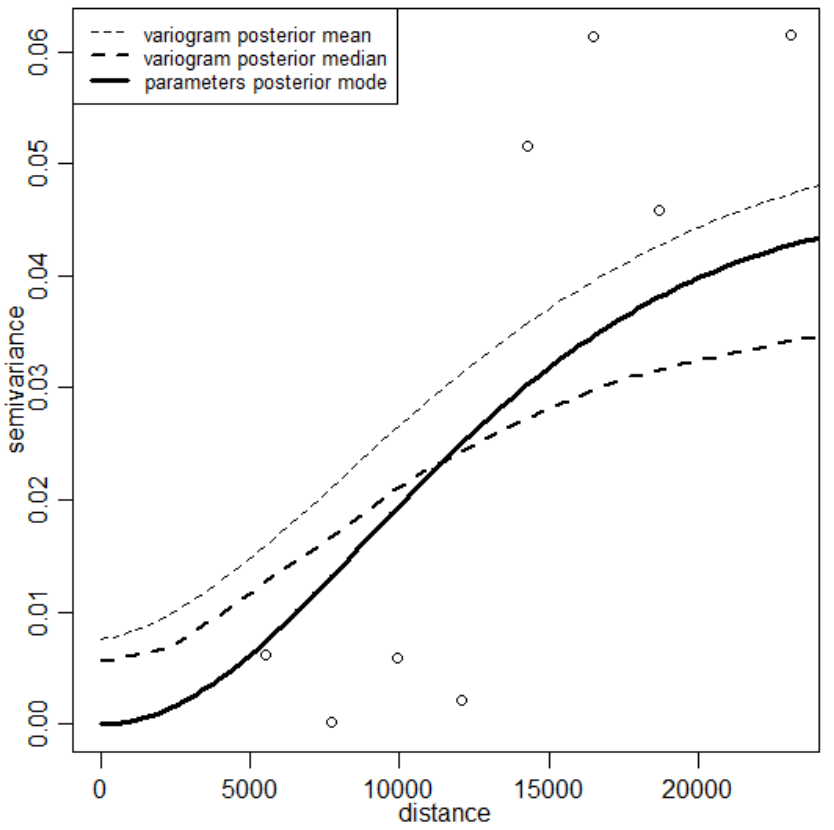

GAMBAR 5. Variogram Empiris dan Bayesian Variogram

Pada gambar di atas, variogram empiris ditunjukkan oleh poin sedangkan variogram teoritis yang akan digunakan untuk kriging ditunjukkan dengan solid line untuk modus parameter variogram posterior, dash line untuk median parameter variogram posterior,dan dot line untuk rata-rata parameter variogram posterior.

\section{Kriging}

Setelah didapat hasil estimasi parameter bayesian variogram, dapat dilakukan kriging pada lokasilokasi yang tidak tersampel. Dalam penelitian ini diambil contoh empat titik lokasi untuk dilakukan kriging, yaitu titik 1,2,3, dan 4 yang berwarna merah pada Gambar 6. Sedangkan titik pada gambar tersebut merupakan lokasi pengukuran polutan timbal di Jakarta (lokasi tersampel).

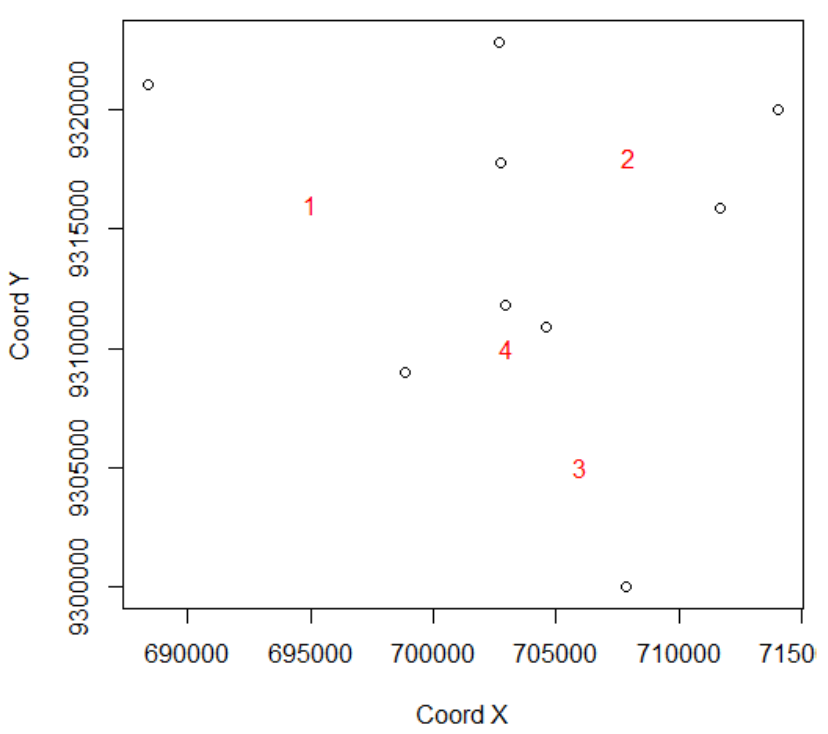

GAMBAR 6. Titik lokasi Kriging

Diperoleh rata-rata dan varians dari setiap titik lokasi yang ditunjukkan pada Tabel 4. 
TABEL 4. Rata-Rata dan Varians Lokasi tidak tersampel

\begin{tabular}{lccccc}
\hline & & Lokasi I & Lokasi II & Lokasi III & Lokasi IV \\
\hline Bayesian & Rata-Rata & 0.3736 & 0.1024 & 0.2065 & 0.1609 \\
\cline { 2 - 2 } Kriging & Varians & 0.0166 & 0.0056 & 0.0054 & 0.0006 \\
\hline Konvensional & Rata-Rata & 0.3645 & 0.1121 & 0.1522 & 0.1577 \\
\cline { 2 - 3 } Kriging & Varians & 0.0107 & 0.0068 & 0.0084 & 0.0034 \\
\hline
\end{tabular}

Berdasarkan Tabel 4 di atas, terlihat bahwa varians hasil prediksi semakin kecil jika jarak lokasi tidak tersampel dengan lokasi tersampel semakin dekat (lokasi ke-4), begitupun sebaliknya. Dilakukan juga perbandingan variansi parameter variogram $\left(\beta=\right.$ nugget, $\sigma^{2}=$ sill, $\phi=$ range $)$ yang dihasilkan bayesian kriging dengan konvensional kriging seperti pada Gambar 7. Garis putus-putus merupakan konvensional kriging sementara garis solid merupakan bayesian kriging. Dapat dilihat bahwa varians dari bayesian kriging cenderung lebih kecil dibandingkan konvensional kriging, terutama untuk lokasi yang terletak berdekatan dengan titik lokasi tersampel (lokasi 3 dan lokasi 4).
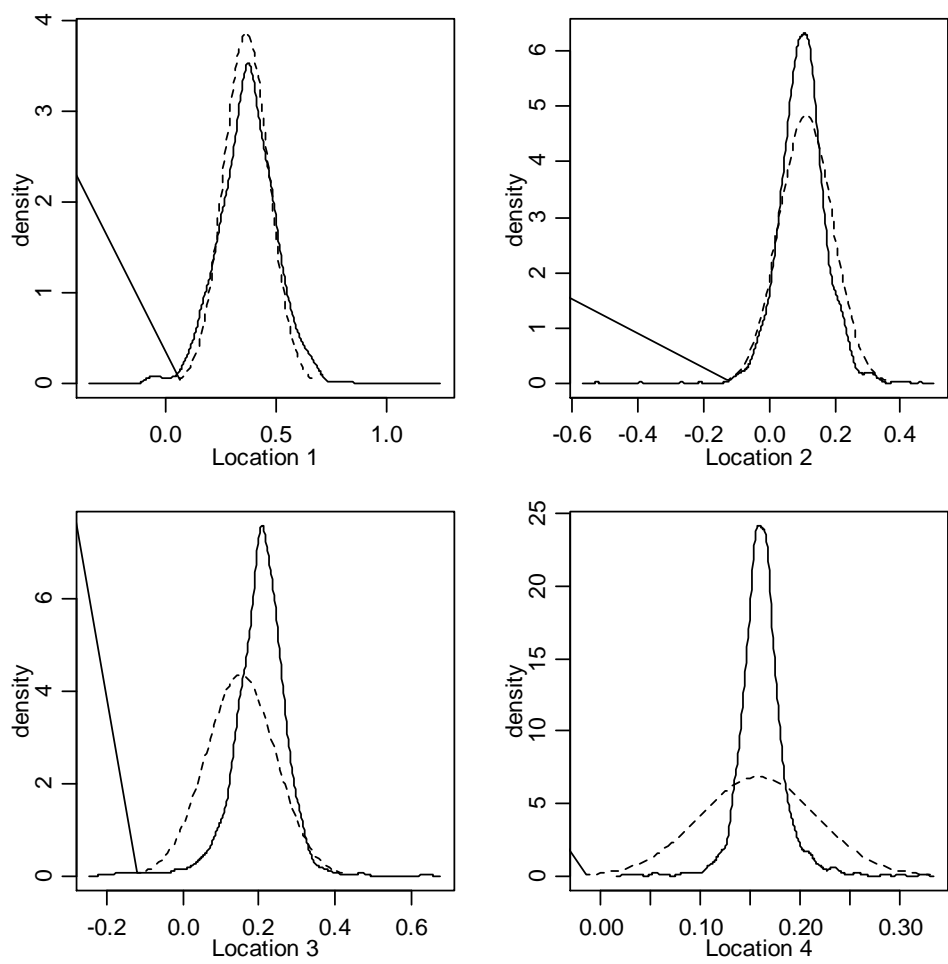

GAMBAR 7. Perbandingan Bayesian Kriging (solid line) dan Konvensional Kriging(dot line)

Selain mengetahui hasil interpolasi polutan timbal pada lokasi tidak tersampel yang telah ditentukan (lokasi 1,2,3, dan 4), dapat diperoleh peta prediksi yang berisi nilai-nilai prediksi maupun varians hasil kriging bayesian pada grid tertentu. Pada penelitian ini dipilih 81 grid seperti pada Gambar 8 dimana makin terang warnanya menunjukkan nilai yang semakin kecil, begitupun sebaliknya. Terlihat bahwa estimasi varians meningkat pada area yang tidak terdapat sampel. 


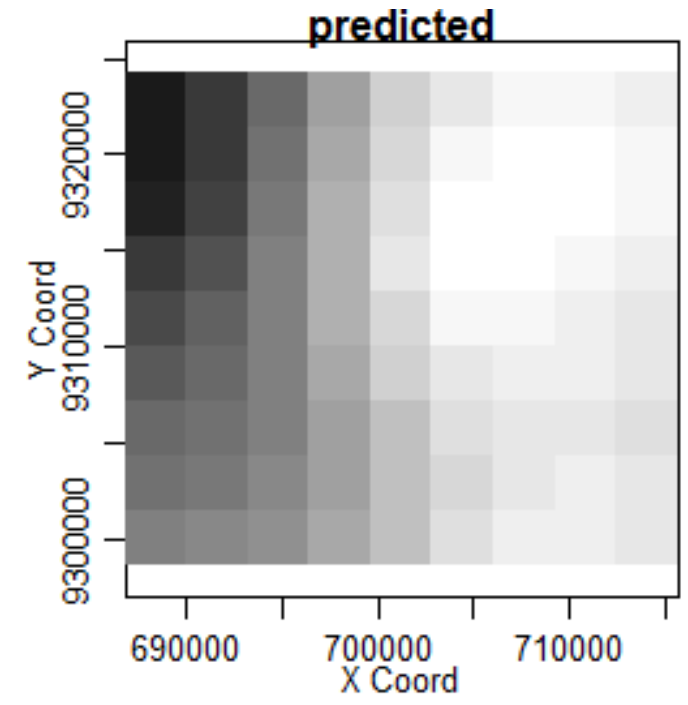

(a) Rata-Rata Prediksi Polutan Timbal

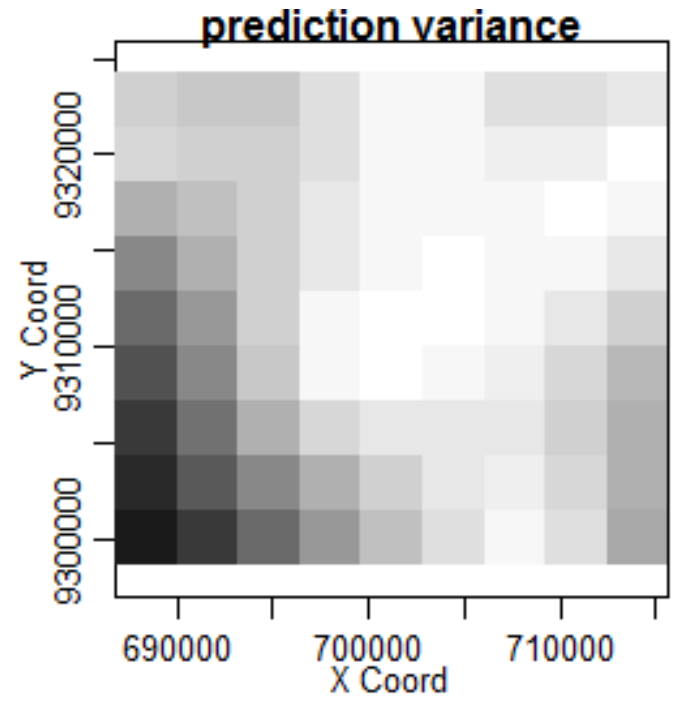

(b) Prediksi Varians Polutan Timbal

GAMBAR 8. Peta 2D rata-rata prediksi dan prediksi varians polutan timbal menggunakan Bayesian Kriging

\section{KESIMPULAN DAN SARAN}

\section{Kesimpulan}

Kriging dilakukan terhadap data polutan timbal pada sembilan titik lokasi sampel di Jakarta. Prediksi dilakukan pada empat titik lokasi secara acak menggunakan perbandingan metode kriging bayesian dan konvensional, diperoleh hasil bahwa varians pada kriging bayesian lebih kecil dibandingkan metode konvensional. Peta prediksi juga dibuat untuk membentuk nilai prediksi dan variansnya dalam bentuk area. Peta dibuat dengan 81 grid, dengan hasil bahwa Jakarta bagian barat memiliki konsentrasi polusi timbal lebih besar daripada Jakarta bagian tengah dan timur.

\section{Saran}

Untuk penelitian selanjutnya dapat menggunakan data pada sektor lain, ataupun membandingkan pada wilayah lainnya. Selain itu dapat menambahkan metode estimasi spasial lainnya.

\section{UCAPAN TERIMA KASIH}

Terima kasih kepada I Gede Nyoman Mindra Jaya, M.Si atas masukan dan bimbingannya untuk penelitian ini.

\section{REFERENSI}

Al-Mudhafar, Watheq J. 2019. Bayesian kriging for reproducing reservoir heterogeneity in a tidal depositional environment of a sandstone formation. Journal of Applied Geophysics 160, hlm.84102.

Diggle, PJ, and Riberio Jr, Paulo J. 2002. Bayesian Inference in Gaussian Model based Geostatistics.

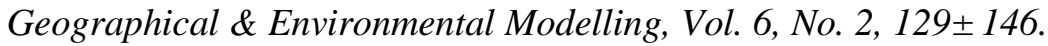

Gusnita, Dessy. Pencemaran Logam Berat Timbal (Pb) Di Udara Dan Upaya Penghapusan Bensin Bertimbal. Berita Dirgantara Vol. 13 No. 3 September 2012:95-101.

Greenpeace Indonesia. 2019. Jakarta Peringkat Satu di Asia Tenggara untuk Kualitas Udara Terburuk. https://www.greenpeace.org/indonesia/siaran-pers/2210/jakarta-peringkat-satu-di-asiatenggara-untuk-kualitas-udara-terburuk/. 
R Development Core Team (2006). R: A language and environment for statistical computing. R Found ation for Statistical Computing, Vienna, Austria. ISBN 3-900051-07-URL http://www.Rproject.org.

Ribeiro Jr., P.J. \& Diggle, P.J. (2001) geoR: A package for geostatistical analysis. R-NEWS, Vol 1, No 2, 15-18. ISSN 1609-3631.

Setiyowati, Devy. 2015. Cokriging Pada Interpolasi Konsentrasi Sulfur Dioksida $\left(\mathrm{SO}_{2}\right)$ Dan Nitrogen Dioksida $\left(\mathrm{NO}_{2}\right)$ di DKI Jakarta. Tesis: Institut Teknologi Sepuluh November. 